\title{
INTERNAL R\&D AND EXTERNAL INFORMATION IN KNOWLEDGE-INTENSIVE BUSINESS SERVICE INNOVATION: COMPLEMENTS, SUBSTITUTES OR INDEPENDENT?
}

\author{
David DOLOREUX ${ }^{1,2^{\star}}$, Richard SHEARMUR ${ }^{3}$, Mercedes RODRIGUEZ ${ }^{4}$ \\ ${ }^{1}$ HEC Montréal, Department of International Business, 3000, chemin de la Côte Sainte Catherine, \\ Montreal, QC, H3T 2A7, Canada \\ ${ }^{2}$ KEDGE Business School, 680 Cours de la Libération, 33405 Talence, France \\ ${ }^{3}$ School of Urban Planning, McGill University, 815 Sherbrooke West, Montreal, QC, H3A 2K6 Canada \\ ${ }^{4}$ Department of International and Spanish Economics, University of Granada, Granada, Spain
}

Received 18 October 2016; accepted 20 January 2018

\begin{abstract}
This paper analyses the effect of internal R\&D and of external sources of information on the innovation performance of Knowledge intensive business services (KIBS). The analysis is based on an establishment-level survey covering the period of 2011-2014 in Canada (Quebec). In order to determine the influence of different external information sources on innovation and the extent to which internal R\&D and the use of external information sources are related to innovation, a series of logistic regressions are performed on four different measures of innovation. The results show that KIBS innovation is positively connected to market-related information sources (but not to research and academic sources), that KIBS innovation is positively associated with the performance of $R \& D$, and that there are no synergies associated with the combined performance of $R \& D$ and external information gathering: their effects are independent and additive. These results share some similarities, but also some important differences, with those that have been obtained from the study of $R \& D$ and external information sourcing in manufacturing establishments.
\end{abstract}

Keywords: R\&D, external sources of innovation, innovations, KIBS, Canada, logistic regression.

JEL Classification: L84, O31.

\section{Introduction}

It is well known that innovation is strongly dependant on external knowledge sources (Battisti, Gallego, Rubalcaba, \& Windrum, 2014; Rodriguez, Doloreux, \& Shearmur, 2015; Love, Roper, \& Vahter, 2014). Thus, innovative firms cannot solely rely on their internal knowledge and experience and require the acquisition of external knowledge and know-how from different sources such as clients and suppliers, competitors, universities, R\&D institutes, and so on.

\footnotetext{
*Corresponding author. E-mail: david.doloreux@hec.ca
}

\section{(C) 2018 The Author(s). Published by VGTU Press}

This is an Open Access article distributed under the terms of the Creative Commons Attribution License (http://creativecommons. org/licenses/by/4.0/), which permits unrestricted use, distribution, and reproduction in any medium, provided the original author and source are credited. 
A number of empirical contributions have investigated the relationship between innovation and the use of different external innovation sources (Battisti et al., 2014; Rodriguez, Doloreux, \& Shearmur, 2016; Love et al., 2014; Santamaría, Nieto, \& Barge-Gil, 2010; BargeGil, 2013). However, empirical studies present ambiguous results and it is unclear whether interaction with particular information sources or with a broad variety of them matters for innovation. This ambiguity may be a consequence of ignoring certain factors that affect the relationship between innovation and external information sources.

Extending previous research on innovation and knowledge sourcing activities, this paper explores the link between: i) internal R\&D and innovation; ii) external sources of information and innovation; and iii) whether the two factors combined have a greater connexion with innovation than each considered separately. Drawing on theoretical knowledge from the disciplines of innovation and service studies, this paper adds to the debate on service innovation (specifically KIBS), analysing the extent to which internal R\&D influences the effect of different external information sources.

The paper thus considers two key factors of KIBS innovation, one internal and one external: the former is in-house $\mathrm{R} \& \mathrm{D}$, a key internal capacity allowing KIBS to assimilate information and knowledge and perform innovation (Doloreux, Shearmur, \& Rodriguez, 2016; Miles, 2008). The latter corresponds to sources of information that lie outside the firm, as it has been shown that firms rarely innovate alone and usually have recourse to different external sources (Clausen, Korneliussen, \& Madsen, 2013).

The following question is analysed: are $\mathrm{R} \& \mathrm{D}$ and external information sources complements, substitutes or independent of one another? Three possible scenarios may occur: first, if they are complements there will be positive interaction effects: the probability of innovating when both R\&D and external information are used will be significantly higher than if only or only the other is used. Second, if they are substitutes, the use of internal R\&D and different sources of information will each contribute significantly to innovation but there will be no advantage to performing both. Third, if they act independently, then each will contribute to innovation, but they will not interact: their effects on establishment-level innovation are simply additive.

The context of the study is KIBS establishments in the province of Quebec (Canada). The analysis is based upon data from an original survey of 502 KIBS establishments. The article contributes to the empirical innovation literature in three ways. First, the effect of R\&D on KIBS innovation is underexplored empirically as is, second, the role of (external) information sources: this paper contributes to these two areas of enquiry. The third contribution, an analysis of the interplay between R\&D and external information sources, speaks to the wider question of the complementarity, substitutability or independence of internal and external resources in KIBS innovation.

Although the underlying motivation of this paper is to explore factors of innovation (innovation is the dependent variable), the empirical analysis is descriptive and exploratory. The cross-sectional questionnaire is structured in such a way that we cannot assign causal connections between innovation, R\&D and external information. Rather, our results can only reveal whether they tend to occur within the same KIBS establishments: this is a first step towards causal analysis, which would require panel data and/or a questionnaire that directly probes the timing of these activities. 
The paper is structured as follows. Section 1 provides the theoretical context and discusses the literature on the relationship between $R \& D$, information sources and innovation. From this literature, three hypotheses are derived. Section 2 discusses the data and methodology. Section 3 presents the results, and the last section summarizes and concludes.

\section{Theoretical background and hypotheses}

Innovation occurs under different modalities, some of which are determined by recourse to a range of internal and external knowledge and information sources. The open innovation model emphasises external sources of knowledge and information which, it is argued, have become key resources for the development of innovation (Battisti et al., 2014; Clausen et al., 2013; Love et al., 2014). This stands in contrast to the traditional model of innovation, which portrays innovation as a process - often linear but sometimes with feedbacks - where firms mainly rely on knowledge created internally, usually through internal R\&D and human capital: here, innovation is characterized by a relatively weak need for knowledge integration from external sources (Rothwell, 1991). However, much of the current research on internal capabilities, external knowledge resources and innovation has focused on manufacturing establishments and on technological innovation: their findings may not apply to the service sector: the nature of innovation activities in service firms may differ (Doloreux et al., 2016; Miles, 2008), as may the forms of innovation.

This section discusses antecedents relevant to the research framework and derives corresponding hypotheses. The framework proposes three key factors that are related to innovation: i) the use of external information and knowledge sources, ii) the use of in-house $R \& D$, and /or iii) a combination of both. Whilst the discussion below draws upon the service and KIBS literature where possible, results from studies of manufacturing sectors are also referred to since they constitute the bulk of the literature in this area.

\subsection{The role of different sources of information for service innovation (KIBS): hypothesis I}

Current theoretical and empirical research recognises that to conceive innovation as solely the result of internal acts by firms is misleading since innovative firms have recourse to external knowledge sources to develop new concepts and ideas. It is well established that firms cannot generate innovation relying solely on their internal knowledge and experience: innovation requires the acquisition of at least some external knowledge and know-how (Cassiman \& Valentini, 2016; Monteiro, Mol, \& Birkinshaw, 2017). External knowledge and information can reside in competing firms, in firms active in downstream and upstream industries along the production value-chain (i.e. users and suppliers), and in institutions outside the industrial system (e.g. universities, research institutes etc.). External knowledge and information can also be obtained from other general sources (Web, conferences, etc.). In this context, knowledge from external sources is perceived as a critical element in the innovation process allowing firms to increase and complement their own ideas and technologies (Tödtling, Lehner, \& Kaufmann, 2009). 
In the service sector, clients play a key role, innovation being more reliant on soft sources of knowledge (Pina \& Tether, 2016; Mina, Bascavusoglu-Moreau, \& Hughes, 2014; Doloreux \& Shearmur, 2013; Miles, 2008; Freel, 2006). One fundamental characteristic of services is the importance placed on the relationship with clients: indeed, Bettencourt, Ostrom, Brown, and Roundtree (2002) stress that KIBS' value-added activities consist primarily in the accumulation, creation and dissemination of knowledge for the purpose of developing customized services to satisfy client needs.

Information from suppliers likewise contributes to innovation, particularly for Technological-KIBS - R\&D services, engineering services, and computer services - since they are intensive users of scientific and technological knowledge (Freel, 2006). Mansury and Love (2008) show that greater customer input (in terms of ideas and suggestions) leads to higher probabilities of innovation. Information sourcing from competitors may also help firms accelerate capability building through $\mathrm{R} \& \mathrm{D}$ collaboration and technological development, enabling firms to differentiate themselves from competitors with respect to technology strategies (Belderbos, Carree, Lokshin, \& Fernández-Sastre, 2004): however, the use of knowledge sourced from competitors is less common and less likely to be associated with higher levels of innovativeness.

Hypothesis 1a. KIBS that acquire external information from clients and suppliers are more likely to develop innovation. Whilst clients and suppliers can provide information relevant to new products and to marketing, they are less likely to have an impact on internal innovation related to management and human resources.

Universities and research organisations are important knowledge and information sources that create and disseminate scientific knowledge (Vivas \& Barge-Gil, 2015). Services (in particular KIBS) can be used by firms to acquire highly specific knowledge and information in order to develop solutions to particular problems or needs (Shearmur \& Doloreux, 2015): exchange of information with these sources has a higher impact on technologically more complex and radical innovations. Vivas and Barge-Gil's (2015) review highlights the key role played by universities, research institutes and KIBS in fostering innovation outputs, in particular product innovations. Focusing on the particular case of services, Mina et al. (2014) show that, although much emphasis has been put on the importance of clients for service innovation, higher benefits can be obtained from information provided by universities and the public research base.

Hypothesis 1b. KIBS that acquire external information from universities, research institutes and consultants (KIBS) are more likely to develop innovation, in particular new products (or services).

Other sources of information can be conference attendance, trade fairs and exhibitions, business associations, and access to scientific and specialised journals. These types of information can be classify as "potential" information that firms are exposed to, as opposed to information from market or institutional sources that are described as "realised" information, information that has been obtained (Zahra \& George, 2002). The nature of this information being general, it is expected that it can be associated with all types of innovation.

Hypothesis 1c. KIBS that acquire external information from generally available sources are more likely to develop all types of innovation. 


\subsection{In-house R\&D in services (KIBS): hypothesis II}

$\mathrm{R} \& \mathrm{D}$ plays an important role in innovation and its role as a determinant of innovation has been repeatedly emphasized (Becheikh, Landry, \& Amara, 2006). R\&D in services is defined as: "creative work undertaken on a systematic basis in order to increase the stock of knowledge, including knowledge of man, culture and society (particularly knowledge of the behaviour of economic agents and that of productive organizations), and the use of this stock of knowledge to devise new applications (whether they involve goods, services, processes, methods or organizations)" (Djellal, Francoz, Gallouj, Gallouj, \& Jacquin, 2003, p. 427).

This definition highlights two objectives of $R \& D$. The first is to create new knowledge in view of developing new products or services, creating new markets, and identifying new needs for emerging customers and markets (Prajogo, C. M. McDermott, \& M. A. McDermott, 2013). The second is to improve existing knowledge to incrementally improve existing products and services to respond to market/customers' needs (Prajogo et al., 2013). In contrast to $\mathrm{R} \& \mathrm{D}$ in manufacturing, this definition is wider, including research in the social sciences and psychology: as such, it moves $\mathrm{R} \& \mathrm{D}$ out of the laboratory, defining it as something that can also take place in offices, libraries and by way of observation, focus groups and surveys.

Despite Djellal's et al. (2003) widening of the definition, a review of the literature on innovation in services indicates that $\mathrm{R} \& \mathrm{D}$ is still under-researched compared with manufacturing (Doloreux et al., 2016; Miles, 2008). Furthermore, Doloreux et al. (2016) argue that R\&D is often understood, by KIBS respondents themselves, as only being related to technology: thus the reporting of R\&D in KIBS surveys does not reflect Djellal's et al. (2003) definition, but tends to record technological $R \& D$ that is associated with technological innovation, limiting its connection to organisational or marketing innovation of the sort most often introduced by services (Freel, 2006; Tether, 2005). Therefore innovation in services is understood less as the result of $\mathrm{R} \& \mathrm{D}$ than of developing and converting various types of knowledge in view of introducing new services, expanding markets or streamlining existing service provision (Miles, 2008).

Notwithstanding this view, R\&D activity and intensity within services is increasing (Doloreux et al., 2016). Even though the recorded scale of $R \& D$ activity in services is more modest than in manufacturing, some research shows that service firms engaged in R\&D are likely to have a stronger capacity to innovate (Miles, 2008). Thus, in contrast to the view that R\&D plays a negligible role in service innovation, another body of work (Pina \& Tether, 2016; Doloreux et al., 2016; Battisti et al., 2014; Prajogo et al., 2013; Miles, 2008) recognises R\&D as a driver of service innovation, and considers it an effective way to develop new knowledge inside firms.

In sum, the literature shows that, in manufacturing firms, $R \& D$ is a key factor that affects innovation. For services, however, there are limited studies that analyse $R \& D$, and no consensus emerges, maybe because of the difficulty in defining and recording R\&D in the service sector. In keeping with some of the KIBS evidence as well as the manufacturing evidence, we formulate the following hypothesis:

Hypothesis 2. KIBS that report in-house R\&D activities are more likely to develop technological innovation related principally to new products. 


\subsection{The interaction between different sources of information and in-house R\&D for service innovation (KIBS): hypothesis III}

It has been emphasised that the ability to combine internal and external information sourcing contributes significantly to innovation (Bianchi et al., 2016; Spithoven \& Teirlinck, 2015; Dahlander \& Gann, 2010). Cassiman and Valentini (2016) indicate that innovation depends on firms' ability to organize, source and exploit both internal and external knowledge and information resources to develop and sustain innovation. These activities can be complementary (when firms undertake both internal and external activities), but could also be substitutes (when firms have recourse to external resources as an alternative to internal ones). Another possibility, rarely made explicit, is that the two activities may be independent of one another: i.e. the processes that connect internal R\&D with innovation may be unrelated to those that connect external information to innovation.

Notwithstanding the possibility of independence, from an innovation perspective it is usually understood that the combination of internal and external knowledge sourcing is a critical source of competitive advantage. This implies that whatever the role played by external knowledge and information, firms' internal resources remain crucial, since without them firms lack the know-how and capabilities to absorb and exploit what is learned from the outside (Dahlander \& Gann, 2010). These capabilities result in part from previous processes of investment and knowledge accumulation within firms, and are closely related to their "absorptive capacity" (Cohen \& Levinthal, 1990).

There are several reasons to believe that $\mathrm{R} \& \mathrm{D}$ and information sourcing complement each other. First, in-house capabilities should increase the capacity of firms to source information externally, which in turn will lead to further expanded in-house knowledge capabilities (Denicolai, Ramirez, \& Tidd, 2016). Second, it can help to decrease the cost and time of new idea development and enable easier access to the resources required to innovate (Cassiman \& Valentini, 2016).

However, recent research on possible complementarity of in-house R\&D and external knowledge on innovation performance yields conflicting results. Several studies find that these activities are complementary. Some studies find that firms conducting R\&D have a larger of number of external links and use external knowledge sources more intensively. Cassiman and Veugelers (2006) show that R\&D and external knowledge acquisition are complementary with respect to innovation, but the degree of complementarity will differ according to other elements of firm's strategic environment. Other studies conclude that adoption of mixed innovation strategies generates positive effects on firms' performance as a result of complementarities between internal innovation activities (such as R\&D) and external knowledge sourcing (Love \& Roper, 2009; Vega-Jurado, Gutiérrez-Gracia, \& Fernández-de-Lucio, 2009). Still other studies find little support for such complementarity: Love et al. (2014) in a longitudinal study of Irish manufacturing firms find no direct evidence of complementarity but find that firms that articulate a strategy on R\&D and acquisition of external knowledge are more innovative over time. Cassiman and Veugelers (2016) test for complementarity in 'buy or sell' strategies for R\&D with respect to innovation. They find no complementarity and show that buying and selling knowledge increase sales of new products. Finally, Doloreux and 
Shearmur (2013) in a study of Canadian manufacturing find no evidence of complementarity between R\&D and external knowledge sources.

In addition, recent studies highlight that the complementarity between in-house R\&D and external knowledge depends on the type of partner and varies over time. For instance, Chen, Wanhaverbeke, and Du (2016), in their study of Chinese manufacturing firms find that, while there is clear complementarity between in-house $R \& D$ and external knowledge from customers, users and suppliers, there is no complementarity between internal R\&D and external knowledge from universities and research institutes. The works of Belderbos, Carree, Lokshin, and Fernández-Sastre (2015) or Denicolai et al. (2016) point out that the relationship between in-house $\mathrm{R} \& \mathrm{D}$ and external knowledge varies over time. In general, engaging simultaneously in internal $\mathrm{R} \& \mathrm{D}$ and external knowledge sourcing improves innovation performance, although it takes more time to benefit from knowledge from universities and research sources than from knowledge obtained from clients or suppliers.

In sum, the literature has focused on the relationship between $\mathrm{R} \& \mathrm{D}$ and external information sourcing, though mainly with respect to manufacturing and technological innovation. Its findings - which do not all point in the same direction - may not apply to the service sector. Whatever the causal processes linking external information sources and innovation, $\mathrm{R} \& \mathrm{D}$ activities may perform a catalysing role by easing the appropriation and use of acquired information.

Hypothesis 3. The combination of internal $R \& D$ and the acquisition of external information from different sources has a positive effect on KIBS innovation. This will be more pronounced for information from customers, users and suppliers, and less so for information from universities and research institutes. In all cases it should be more pronounced for technological (new product) innovation.

\section{Research design}

\subsection{The choice of the KIBS sector}

Following the lead of many other studies of innovation in the service sector, this study focuses on KIBS (Tether, Li, \& Mina, 2012; Doloreux \& Shearmur, 2013; Freel, 2006; Miles, 2008). KIBS is a knowledge-intensive industry characterized by high rates of innovation: this does not just consist in adopting (and adapting) technology and management techniques, but also in conceiving new services, processes, management strategies and marketing approaches. To introduce new services, KIBS require new information or new knowledge combinations resulting from the acquisition, assimilation and exploitation of new competencies and - we hypothesize - from the performance of in-house R\&D.

\subsection{Data}

The empirical analysis is based on data from an establishment-level survey covering the period of 2011-2014. The survey provides information on the innovation activities of KIBS establishments in Canada (Quebec). Quebec is a Canadian province of 8000000 people: it 
has its own language, considerable policy and taxation autonomy, and its geography - two major metropolitan areas, a few smaller cities, and vast areas of virtually uninhabited land resembles that of Nordic European countries. Montreal is a minor global city (Derudder \& Taylor, 2016) - its financial, legal and accounting sectors are secondary relative to nearby New York and Toronto, but its computer, creative and engineering services have carved out global niches in activities such as videogames, construction and mining services. Quebec City is the seat of government, with numerous consulting activities gravitating around the city's public sector. Given that French is the working language in Quebec, its KIBS sector is somewhat more self-contained than that of other Canadian or US states and provinces, with Montreal playing a dominant role (Polèse \& Shearmur, 2004).

The survey method and questionnaire are inspired by the Survey of Innovation and Business Strategy (Statistics Canada), the Community Innovative Survey, and the third edition of the Oslo Manual of the Organization for Economic Cooperation and Development (OECD, 2005). The data were collected through telephone survey, performed by a private survey company which conducted interviews using Computer Aided Telephone Interviewing (CATI). The questionnaire consists of three parts. The first requests information on service innovations. The second includes questions on innovation activities and information sources used in the innovation process. The third requests information about the establishment.

These data constrain our ability to investigate causal connections. Indeed, the panel structure is such that we are able to establish whether, over the three years preceding the survey, the establishment has innovated, obtained information from various sources and/ or performed $R \& D$, but we have no information on the sequence of events nor on whether the establishment itself considers that there is connection between the events. Thus, our empirical results are descriptive and establish correlations (controlled for possible confounding factors). These correlations may corroborate certain causal hypotheses (as derived from our reading of the literature and our understanding of the innovation process), but cannot establish causal connection: thus, absence of correlation is a strong indicator that no causal connection exists, but presence of correlation merely indicates that the causal connexion may exist.

The sample is representative of the population of KIBS establishments in Quebec (excluding establishments with over 500 employees) identified from the CRIQ (Centre de Recherche Industrielle du Québec) establishment database: a stratified random sampling process generated the sampling frame according to firm size, KIBS industry and location (see Appendix, Table A1 for assessment of representativity). The database includes 502 establishments. The sample covers five KIBS sub-industries: i) Architectural, engineering and related services (NAICS 5413); ii) Management, scientific and technical consultants (NAICS 5416); iii) Computer systems design and related services (NAICS 5415); iv) Other professional KIBS, which include Legal services (NAICS 5411) and Accounting (NAICS 5412); and, v) Other creative KIBS, which include Specialized design services (NAICS 5414) and Advertising, public relations, and related services (NAICS 5418). The sample corresponds to 20.0\% (502/2508) of the population. 


\subsection{Variables and analytical procedure}

In order to determine the extent to which $\mathrm{R} \& \mathrm{D}$ and the use of external information sources are related to service innovation, a series of logistic regressions are performed on four different measures of innovation: service innovation; new human resources practices; new management strategy; new marketing and commercialisation strategy. These types of innovation are defined in the questionnaire as follows. Service innovation is the introduction of any new or significantly improved product (service). Human resource innovation is the introduction of any new or significantly improved management strategy related to human resources, recruitment, and employees. Management innovation relates to the introduction of any new or significantly improved business strategy, including computer systems and knowledge management practices. Finally, marketing innovation relates to new or significantly modified marketing strategies and concepts (such as new marketing methods).

To explore H1a to H1c, we introduce eleven different external information sources. These sources are market sources, which include i) clients; ii) suppliers; iii) competitors, and iv) consultants; institutional sources, which include v) universities, vi) colleges, vii) commercial labs, and viii) federal and provincial governments; and other sources, which include: ix) business associations, $x$ ) conferences and trade fairs, and xi) investors. The survey asks: "Over the last three years, please indicate, from the list of sources below, those that play an important role in contributing ideas for the development of your services". For each source, a three-point scale is proposed: 1 means "little importance", while 3 means "high importance". In all cases the variables have been dichotomized, with the source coded " 1 " if it is categorized as "high importance". From these eleven sources of information, four principal components have been extracted, accounting for $56 \%$ of total variance: this component solution is of only moderate power, but the components are interpretable and no variables load onto more than one component (see Appendix, Table 2A). The components, after orthogonal rotation, are named as follows: i- scientific and technical sources; ii- investors and conferences; iii- suppliers and internet; and, iv- clients (+) or consultants (-). It is interesting to note that these components do not combine information sources in quite the same way as they are discussed in the literature: for example, whereas clients and suppliers have often been analysed together, they load onto different components. Likewise general sources - such as the internet and conferences - do not combine. Although this is not the focus of the paper, the component solution suggests that standard classifications of information sources do not always apply, or apply differently to KIBS than to manufacturing establishments (from which they have been derived).

A cluster analysis with a five cluster solution is performed on the factor scores to explore whether specific combinations of information sources are related to innovation. There is no definitive solution to a hierarchical cluster analysis: a five cluster solution was chosen based on three criteria: a break-point in the evolution of the semi-partial R2 (i.e. the explanatory power lost from moving 6 to 5 clusters is modest compared to moving from 5 to 4 ), a small number of clusters (so that the analysis remains tractable), and a proportion of total variance explained superior to $50 \%$ (74.9\% in this case). 
To explore H2, we include a dummy variable for R\&D. The survey asks "during the three years preceding this survey, has your establishment undertaken R\&D in view of developing new or significantly improved services, process, organisational and marketing innovation?" $\mathrm{R} \& \mathrm{D}$ is defined as "creative and systematic work undertaken in order to increase the stock of knowledge -including knowledge of humankind, culture and society- and to devise new applications of available knowledge" (OECD, 2005, p. 44). The R\&D variable is dichotomous. Despite this indicator's lack of granularity it provides useful insight, as the empirical analysis that follows will reveal.

To explore hypotheses H1a, H1b, H1c and H2, the block of four information-source components and the internal R\&D variable are each inserted alone, and the degree to which they augment the "controls only" model is examined. In the case of $\mathrm{H} 1$, dummy variables for the five clusters were also tested, but did not perform as well as introducing the factors directly: these analyses are available upon request.

To explore H3, information sources and internal R\&D are inserted together, and interaction terms between $R \& D$ and the four components are also explored. Two elements are analysed: first, the extent to which $\mathrm{R} \& \mathrm{D}$ and information sources act independently. Two cases are possible. If $\mathrm{R} \& \mathrm{D}$ and information sources are substitutes, and account for essentially the same variability in the probability of innovation, the overall explanatory power of the model that includes either one will not greatly increase when both are included. Alternatively, $\mathrm{R} \& \mathrm{D}$ and information sources may relate independently to innovation: if this is the case, the extra explanatory power of the model (over and above the "controls only" model) will approximately be the sum of the explanation added by R\&D alone and by information sources alone. The second element that is analysed is the interaction between R\&D and information sources. It is possible that $\mathrm{R} \& \mathrm{D}$ and information each contribute independently and significantly to understanding the propensity to innovate, but that they also interact - in which case establishments that combine R\&D with intensive use of information sources will have a higher probability of innovating. This would point to $\mathrm{R} \& \mathrm{D}$ and information sources being synergistic, the one enhancing the other in the innovation process.

In all logistic regressions a series of control variables is included. The variables are grouped into four categories. First, we control for size, measured as the number of employees. There are four dummy variables that represent size: 1-9, 10-24; 25-49; and 50 and more employees. Second, we control for exports, measured as the percentage of sales in foreign markets. In alignment with the literature (Rodríguez \& Nieto, 2012), three dummy variables categorize establishments by percentage of sales completed abroad: i) no international sales ( $0 \%)$; ii) ad hoc international sales (1-24\%); and, iii) established international sales (25-100\%). Third, we control for the milieu within which KIBS operate: it is often posited that metropolitan regions foster knowledge exchange and innovation. Four dummy variables represent different types of milieu: city of Montreal; city of Quebec; central regions (within 100km of a metropolitan area); peripheral and rural regions. Finally we control for five KIBS sectors: as Tether et al. (2012) have recently argued, the distinction between Technological-KIBS and Professional-KIBS is not fine enough: our data allow us to break the sample down into i) Management, Scientific and Tech. consulting; ii) other professional KIBS; iii) creative KIBS; iv) Architectural, engineering and related services; and v) Computer system designs and related services. Descriptive statistics are presented in Table 1. 
Table 1. Descriptive statistics

\begin{tabular}{|c|c|c|}
\hline Dependent variables & Number & $\%$ \\
\hline $\begin{array}{l}\text { Service innovation } \\
\text { Human resources innovation } \\
\text { Management innovation } \\
\text { Marketing innovation }\end{array}$ & $\begin{array}{l}308 \\
212 \\
212 \\
173\end{array}$ & $\begin{array}{l}61.4 \\
42.2 \\
42.2 \\
34.5\end{array}$ \\
\hline Independent variables & Number & $\%$ \\
\hline $\begin{array}{l}\text { Firms engaged in } \mathrm{R} \& \mathrm{D} \\
\text { External sources } \\
\text { (\% of KIBS who consider the following sources as high importance) }\end{array}$ & 351 & 69.9 \\
\hline $\begin{array}{l}\text { Clients } \\
\text { Suppliers } \\
\text { Consultants (other KIBS) } \\
\text { Commercial labs } \\
\text { University } \\
\text { Technical college } \\
\text { Public laboratory } \\
\text { Private research institute } \\
\text { Conferences and trade fairs } \\
\text { Internet } \\
\text { Investors }\end{array}$ & $\begin{array}{l}348 \\
111 \\
278 \\
48 \\
133 \\
75 \\
69 \\
45 \\
123 \\
316 \\
86\end{array}$ & $\begin{array}{r}69.3 \\
22.1 \\
55.4 \\
9.6 \\
26.5 \\
14.9 \\
13.8 \\
9.0 \\
24.5 \\
63.0 \\
17.1\end{array}$ \\
\hline Control variables & Number & $\%$ \\
\hline $\begin{array}{l}\text { Size } \\
1-9 \text { employees } \\
10-24 \text { employees } \\
25-49 \text { employees } \\
50 \text { employees and more }\end{array}$ & $\begin{array}{c}202 \\
151 \\
85 \\
64\end{array}$ & $\begin{array}{l}40.2 \\
30.1 \\
16.9 \\
12.8\end{array}$ \\
\hline $\begin{array}{l}\text { Exports } \\
\text { No export } \\
1-24 \% \text { of sales } \\
25 \% \text { and more of sales }\end{array}$ & $\begin{array}{c}343 \\
98 \\
61\end{array}$ & $\begin{array}{l}68.3 \\
19.5 \\
12.2\end{array}$ \\
\hline $\begin{array}{l}\text { Sectors } \\
\text { Architecture } \\
\text { Computer services } \\
\text { Management consulting } \\
\text { Creative services } \\
\text { Other P-KIBS }\end{array}$ & $\begin{array}{c}123 \\
131 \\
112 \\
67 \\
69\end{array}$ & $\begin{array}{l}24.5 \\
26.1 \\
22.3 \\
13.4 \\
13.8\end{array}$ \\
\hline $\begin{array}{l}\text { Location } \\
\text { Montreal } \\
\text { Quebec } \\
\text { Central regions } \\
\text { Peripheral regions }\end{array}$ & $\begin{array}{c}239 \\
126 \\
77 \\
60\end{array}$ & $\begin{array}{l}47.6 \\
25.1 \\
15.3 \\
12.0\end{array}$ \\
\hline
\end{tabular}

\section{Empirical results}

In general, KIBS establishments that place high importance on external information sources are more innovative than those that don't (Table 2). H1a, which posits a connection between external information sources and innovation, is therefore globally verified. There are, however, some important provisos which emerge when the sub-hypotheses are considered. 
Indeed, it is not all types of information source that are positively connected with innovation. Research and knowledge sources, for instance, are not associated with any type of KIBS innovation; client-sourced information is not associated with marketing innovation, but is strongly associated with product innovation.

$\mathrm{H} 1 \mathrm{~b}$ is rejected: information from consultants (negative F4) and from research and knowledge sources (F1) is either not associated with innovation, or has a negative association with the probability of innovating. This surprising result may be connected to the time-span covered by the questionnaire: if this type of information source is connected to longer-term and more slowly developed innovations (Shearmur, 2015) then it could be associated with lower innovation rates over the three year time horizon of this study. An alternative interpretation is that firms seeking information from these more formalised sources are less dynamic than those interacting with market-related or ad-hoc sources.

$\mathrm{H} 1 \mathrm{c}$ is difficult to verify because general information sources load onto two components: thus, the concept that underpins the hypothesis is not applicable (as a single concept) to our data. This type of information source is associated both with suppliers (Internet, F2) and with investors (conferences, F3), and both components are positively associated with all types of innovation (except F3 with Human resource innovation).

In short, and notwithstanding the general positive association between the importance assigned to information sourcing and innovation, there is no systematic connection between different types of information source and different types of innovation. The most striking result is the absence of connection (and, in one case, negative connection) between research and knowledge sources and innovation. KIBS innovation is not connected with obtaining information from universities, colleges or labs, at least over a three year time horizon.

With respect to $\mathrm{H} 2$, that posits a positive connection between in-house R\&D and innovation, firms that perform R\&D introduce more Product, Internal management and Marketing innovations (Table 2, column C), thereby globally confirming the hypothesis. The odds ratio is highest for Product innovation (as expected under H2), but remains close to 2 for all types of innovation where the relationship is significant. It is only for Human Resources innovation that the result is not significant, but the odds ratio remains above one. This result is in keeping with research that has been performed on the manufacturing sector and with some - but not all - research on KIBS.

The question, therefore, is why, amongst the non-technological innovation types, human resource innovation is not associated with $\mathrm{R} \& \mathrm{D}$, whereas it is with management and marketing innovations. First, we can point out that odds ratios are greater than one for Human resources innovation - so, there is a positive (but non-significant) association between human resources innovation and R\&D. The question is one of degree, not of direction. Second, whereas in some cases (e.g. product innovation) theory suggests there could be a direct causal link between R\&D and innovation, in other cases (e.g. marketing and management) the link may either be indirect (mediated by product innovation) or the causal process could be reversed (e.g. it is the innovation that "causes" $R \& D$ - for example a new management approach may introduce R\&D). Whatever the causal direction, Internal management and Marketing innovations - unlike human resources - can be introduced quickly in response 
to $\mathrm{R} \& \mathrm{D}$ findings (or, conversely, changes in marketing and management can more quickly lead to R\&D efforts). This suggests that the association between R\&D and Human Resource innovation is weaker than for other types of innovation principally because HR innovation is slower to implement and/or less responsive to short-term changes. So, if R\&D "causes" HR innovation, this will take longer to manifest itself, and, if HR innovation "causes" R\&D, there will be a longer delay between the Human Resource changes and the results of R\&D.

Table 2. The connection between external information sources, R\&D and innovation

\begin{tabular}{|c|c|c|c|c|c|c|c|c|}
\hline & \multicolumn{4}{|c|}{ Product (service) innovation } & \multicolumn{4}{|c|}{ Human resource innovation } \\
\hline & A & $\mathrm{B}$ & $\mathrm{C}$ & $\mathrm{D}$ & A & $\mathrm{B}$ & $\mathrm{C}$ & $\mathrm{D}$ \\
\hline \multicolumn{9}{|l|}{ External sources } \\
\hline \multicolumn{2}{|c|}{ F1: Research and knowledge sources } & 1.014 & & 1.009 & & $0.653^{* * *}$ & & $0.654^{* * *}$ \\
\hline \multicolumn{2}{|c|}{ F2: Investors \& conferences } & $1.339^{* * *}$ & & $1.340^{* * *}$ & & $1.531^{\star * *}$ & & $1.528^{\star * *}$ \\
\hline \multicolumn{2}{|l|}{ F3: Suppliers \& internet } & $1.288^{* * *}$ & & $1.268^{* *}$ & & $1.183^{*}$ & & 1.177 \\
\hline \multicolumn{2}{|c|}{ F4: Clients (+) / consultants (-) } & $1.295^{\star * *}$ & & $1.301^{\star * *}$ & & $1.353^{* * *}$ & & $1.353^{\star * *}$ \\
\hline \multicolumn{9}{|c|}{ Internal $R \& D$} \\
\hline R\&D yes/no & & & $2.580^{* * *}$ & $2.555^{\star * *}$ & & & 1.284 & 1.24 \\
\hline \multicolumn{9}{|l|}{ Controls } \\
\hline Size 10-24 (reference 1-9) & 0.976 & 0.912 & 1.026 & 0.957 & $2.420^{\star * *}$ & $2.361^{* * *}$ & $2.455^{\star * *}$ & $2.389^{* * *}$ \\
\hline Size $25-49$ & 1.139 & 1.135 & 1.152 & 1.128 & $2.055^{* * *}$ & $2.079^{* *}$ & $2.062^{* * *}$ & $2.087^{\star * *}$ \\
\hline Size $50+$ & 1.348 & 1.348 & 1.437 & 1.466 & $1.945^{\star *}$ & $2.011^{\star *}$ & $1.973^{\star *}$ & $2.034^{\star *}$ \\
\hline $\begin{array}{l}\text { Exports } 1-24 \% \\
\text { (reference no export) }\end{array}$ & 1.277 & 1.234 & 1.194 & 1.161 & 0.707 & 0.671 & 0.695 & 0.661 \\
\hline Exports $25 \%+$ & 1.544 & 1.381 & 1.441 & 1.29 & $1.778^{* *}$ & 1.616 & $1.747^{*}$ & 1.592 \\
\hline $\begin{array}{l}\text { Architecture (reference } \\
\text { others P-KIBS) }\end{array}$ & $1.720^{*}$ & $1.869^{*}$ & $2.049^{* *}$ & $2.223^{* *}$ & 0.957 & 1.023 & 0.992 & 1.054 \\
\hline Computer services & $2.619^{* * *}$ & $2.582^{\star * *}$ & $2.672^{* * *}$ & $2.659^{* * *}$ & 1.212 & 1.097 & 1.205 & 1.092 \\
\hline Management consultants & $2.304^{* * *}$ & $2.126^{* *}$ & $2.388^{\star * *}$ & $2.220^{\star *}$ & 1.06 & 0.95 & 1.058 & 0.95 \\
\hline Creative services & $2.176^{\star *}$ & $2.196^{* *}$ & $2.493^{\star *}$ & $2.503^{* *}$ & 0.842 & 0.77 & 0.863 & 0.789 \\
\hline Quebec (ref Montreal) & 0.703 & $0.674^{*}$ & $0.672^{*}$ & $0.646^{\star}$ & 1.176 & 1.149 & 1.17 & 1.145 \\
\hline Central & 0.769 & 0.706 & 0.779 & 0.717 & 1.092 & 1.095 & 1.098 & 1.104 \\
\hline Peripheral & 1.118 & 0.968 & 1.082 & 0.945 & 1.154 & 1.067 & 1.145 & 1.056 \\
\hline nul -2loglikelihood & 669.804 & & & & 683.751 & & & \\
\hline model -2loglikelihood & 649.959 & 628.765 & 628.796 & 608.897 & 656.554 & 609.692 & 655.094 & 608.966 \\
\hline Nagelkerke r2 & $0.053^{*}$ & $0.107^{\star * *}$ & $0.107^{\star * *}$ & $0.155^{\star * *}$ & $0.071^{\star *}$ & $0.184^{\star * *}$ & $0.075^{\star *}$ & $0.184^{\star * *}$ \\
\hline \multicolumn{2}{|c|}{ Chi2 adding block(s) to controls } & $21.194^{* * *}$ & $21.163^{\star * *}$ & $41.062^{* * *}$ & & $46.862^{* * *}$ & 1.46 & $46.588^{\star * *}$ \\
\hline \multicolumn{2}{|c|}{ Chi 2 adding RD to External sources } & & & $19.868^{\star * *}$ & & & & 0.726 \\
\hline \multicolumn{2}{|c|}{ Chi 2 adding External sources to RD } & & & $19.899^{* * *}$ & & & & $46.128^{\star * *}$ \\
\hline $\mathrm{n}$ & 502 & 502 & 502 & 502 & 502 & 502 & 502 & 502 \\
\hline $\mathrm{n}=1$ & 308 & 308 & 308 & 308 & 212 & 212 & 212 & 212 \\
\hline
\end{tabular}


End of Table 2

\begin{tabular}{|c|c|c|c|c|c|c|c|c|}
\hline & \multicolumn{4}{|c|}{ Management innovation } & \multicolumn{4}{|c|}{ Marketing innovation } \\
\hline & A & $\mathrm{B}$ & $\mathrm{C}$ & $\mathrm{D}$ & A & $\mathrm{B}$ & $\mathrm{C}$ & $\mathrm{D}$ \\
\hline \multicolumn{9}{|l|}{ External sources } \\
\hline \multicolumn{2}{|c|}{ F1: Research and knowledge sources } & 0.878 & & 0.875 & & 0.963 & & 0.964 \\
\hline \multicolumn{2}{|c|}{ F2: Investors \& conferences } & $1.440^{* * *}$ & & $1.434^{\star * *}$ & & $1.316^{\star * *}$ & & $1.309^{* * *}$ \\
\hline \multicolumn{2}{|l|}{ F3: Suppliers \& internet } & $1.195^{\star}$ & & $1.182^{\star}$ & & $1.251^{\star \star}$ & & $1.240^{* *}$ \\
\hline \multicolumn{2}{|c|}{ F4: Clients (+) / consultants (-) } & $1.329^{* * *}$ & & $1.330^{* * *}$ & & 0.950 & & 0.951 \\
\hline \multicolumn{9}{|c|}{ Internal $R \& D$} \\
\hline R\&D yes/no & & & $1.919^{* * *}$ & $1.877^{\star * *}$ & & & $1.785^{\star * *}$ & $1.730^{* *}$ \\
\hline \multicolumn{9}{|l|}{ Controls } \\
\hline $\begin{array}{l}\text { Size 10-24 (reference } \\
1-9)\end{array}$ & 0.949 & 0.867 & 0.974 & 0.888 & 1.254 & 1.198 & 1.292 & 1.234 \\
\hline Size $25-49$ & 1.346 & 1.316 & 1.361 & 1.328 & 1.316 & 1.324 & 1.318 & 1.330 \\
\hline Size $50+$ & 1.403 & 1.378 & 1.456 & 1.432 & 1.455 & 1.434 & 1.504 & 1.478 \\
\hline $\begin{array}{l}\text { Exports } 1-24 \% \\
\text { (reference no export) }\end{array}$ & 1.110 & 1.080 & 1.059 & 1.035 & $1.903^{* * *}$ & $1.901^{* * *}$ & $1.843^{* *}$ & $1.845^{\star *}$ \\
\hline Exports $25 \%+$ & $3.602^{* * *}$ & $3.459^{* * *}$ & $3.485^{* * *}$ & $3.356^{* * *}$ & $1.726^{*}$ & 1.561 & $1.666^{*}$ & 1.513 \\
\hline $\begin{array}{l}\text { Architecture } \\
\text { (reference others P-KIBS) }\end{array}$ & 1.524 & 1.659 & 1.692 & $1.834^{*}$ & 1.350 & 1.260 & 1.478 & 1.388 \\
\hline Computer services & 1.480 & 1.393 & 1.470 & 1.385 & 1.447 & 1.285 & 1.443 & 1.290 \\
\hline Management consultants & 1.141 & 1.019 & 1.144 & 1.021 & 1.470 & 1.267 & 1.473 & 1.277 \\
\hline Creative services & 0.880 & 0.839 & 0.932 & 0.895 & 1.322 & 1.277 & 1.409 & 1.374 \\
\hline Quebec (ref Montreal) & 1.400 & 1.378 & 1.382 & 1.359 & 0.924 & 0.917 & 0.907 & 0.902 \\
\hline Central & 1.216 & 1.172 & 1.243 & 1.205 & 1.377 & 1.345 & 1.405 & 1.368 \\
\hline Peripheral & 1.576 & 1.380 & 1.548 & 1.351 & 0.973 & 0.897 & 0.959 & 0.879 \\
\hline nul -2loglikelihood & 683.751 & & & & 646.630 & & & \\
\hline model -2loglikelihood & 651.861 & 624.577 & 642.453 & 616.229 & 631.472 & 617.710 & 624.441 & 611.612 \\
\hline Nagelkerke r2 & $0.083^{\star * *}$ & $0.150^{\star * *}$ & $0.106^{* *}$ & $0.169^{* * *}$ & 0.041 & $0.077^{* *}$ & $0.060^{*}$ & $0.093^{\star * *}$ \\
\hline \multicolumn{2}{|c|}{ Chi2 adding block(s) to controls } & $27.284^{\star * *}$ & $9.408^{\star * *}$ & $35.632^{* * *}$ & & $13.762^{\star * *}$ & $7.03^{* * *}$ & $19.86^{\star * *}$ \\
\hline \multicolumn{2}{|c|}{ Chi 2 adding RD to External sources } & & & $8.348^{\star * *}$ & & & & $6.098^{\star *}$ \\
\hline \multicolumn{2}{|c|}{ Chi 2 adding External sources to RD } & & & $26.224^{* * *}$ & & & & $12.828^{\star * *}$ \\
\hline $\mathrm{n}$ & 502 & 502 & 502 & 502 & 502 & 502 & 502 & 502 \\
\hline $\mathrm{n}=1$ & 212 & 212 & 212 & 212 & 173 & 173 & 173 & 173 \\
\hline
\end{tabular}

Notes: Table 2 presents the odds ratios for each variable. For each model the independent variable is a dichotomous indicator of innovation. For each type of innovation, the models in each column are as follows: A contains only the control variables, $\mathrm{B}$ has the four components of external information sources added to $\mathrm{A}, \mathrm{C}$ has the internal $\mathrm{R} \& \mathrm{D}$ variable added to $\mathrm{A}$, and $\mathrm{D}$ has the four components of external information sourcing and external R\&D added to A. ${ }^{*}$ indicates significant at the $90 \%$ confidence level; ${ }^{\star \star} 95 \%$; ${ }^{\star *} 99 \%$.

The key question addressed in this paper, formalised under hypothesis 3 , concerns whether R\&D and the external sourcing of information can be considered substitutes, complements or are independent. A first element of response can be gleaned from Table 3. There is no correlation between $\mathrm{R} \& \mathrm{D}$ and the importance assigned to information sources: the proportion of firms that perform $\mathrm{R} \& \mathrm{D}$ does not vary across different component scores, and, 
conversely, component scores are identical whether or not an establishment performs R\&D. The two items are statistically independent - which is preliminary evidence that there is no tendency - at least for KIBS - for internal R\&D activities to enhance recourse to external information as the literature suggests.

This lack of connection between the two is confirmed when both are added simultaneously to the base logistic regression (Table 2, column D): the odds-ratios of R\&D and of the four component scores are virtually identical to when they are each added separately (columns B and C), and the decrease in -2loglikelihood (equivalent to chi2) that corresponds to the model with both types of variables (column D) is very nearly the sum of the decreases corresponding to each of the separate models (columns B and C). Likewise, the increase in Nagelkerke R2 of the full model over the control model is virtually the sum of the increases for each individual model. This indicates that internal R\&D and external sourcing of information are almost totally independent, each contributing separately to KIBS innovation. This is also true for Human resource innovation: despite the fact that there is no connection between $R \& D$ and this type of innovation, the key result - that R\&D and external sources appear not to interact, is maintained.

Table 3. Relationship between information sources and R\&D

\begin{tabular}{|l|c|c|c|c|}
\hline \multicolumn{5}{|c|}{ a) Information sources (mean factor scores) by R\&D } \\
\hline & $\begin{array}{c}\text { Factor 1 } \\
\text { by R\&D }\end{array}$ & $\begin{array}{c}\text { Factor } 2 \\
\text { by R\&D }\end{array}$ & $\begin{array}{c}\text { Factor 3 } \\
\text { by R\&D }\end{array}$ & $\begin{array}{c}\text { Factor } 4 \\
\text { by R\&D }\end{array}$ \\
\hline No R\&D & -0.01 & -0.07 & -0.09 & -0.03 \\
\hline R\&D & 0.00 & 0.03 & 0.04 & 0.01 \\
\hline b) R\&D (\% who perform R\&D) as a function of information sources & $\begin{array}{c}\text { R\&D } \\
\text { by Factor } 2\end{array}$ & $\begin{array}{c}\text { R\&D Factor 3 } \\
\text { by Factor } 4\end{array}$ \\
\hline & $\begin{array}{l}\text { R\&D } \\
\text { by Factor 1 }\end{array}$ & $69 \%$ & $65 \%$ & $70 \%$ \\
\hline Low (less than 0.5) & $71 \%$ & $69 \%$ & $73 \%$ & $69 \%$ \\
\hline Med (-0.5 to 0.5) & $69 \%$ & $72 \%$ & $71 \%$ & $71 \%$ \\
\hline High (over 0.5) & $71 \%$ & &
\end{tabular}

Note: there are no significant differences (at the $20 \%$ confidence level) in factor scores across R\&D, nor in the performance of R\&D across factor scores.

As a final verification of this result, the interaction effects between $R \& D$ and information sources have been added to the complete model (Table 4 - control variables not shown). Given the almost total separation of the respective contributions of $R \& D$ and external information sources to the four types of innovation, it comes as no surprise that the interaction terms lack significance across all types of innovation. H3, which reflects the thrust of the literature with respect to interactions between $R \& D$ and external information sources in the manufacturing sector, is emphatically rejected in this study of KIBS establishments. The effects on KIBS innovation of in-house R\&D and external acquisition of information are essentially additive: an establishment that performs both has a higher probability of being innovative than an establishment that only performs one or the other, but there are no synergistic effects. 
Table 4. Interactions between R\&D and information sources

\begin{tabular}{|c|c|c|c|c|}
\hline Innovation type: & Product & $\begin{array}{l}\text { Human } \\
\text { Resources }\end{array}$ & Management & Marketing \\
\hline \multicolumn{5}{|l|}{ Information sources } \\
\hline F1: Research and academic sources & 0.995 & $0.584^{\star \star}$ & 0.783 & 0.899 \\
\hline F2: Investors \& conferences & $1.477^{\star \star}$ & $1.721^{\star \star \star}$ & $1.806^{\star * *}$ & 1.172 \\
\hline F3: Suppliers \& internet & 1.192 & $1.686^{\star * *}$ & $1.437^{\star}$ & 1.293 \\
\hline F4: Clients $(+) /$ consultants (-) & 1.185 & $1.412^{\star}$ & $1.479^{* *}$ & 1.088 \\
\hline \multicolumn{5}{|l|}{ Internal $R \& D$} \\
\hline R\&D yes/no & $2.569^{* * *}$ & 1.246 & $1.897^{* * *}$ & $1.732^{* *}$ \\
\hline \multicolumn{5}{|l|}{ Interaction $R \& D{ }^{*}$ Information sources } \\
\hline $\mathrm{F} 1 * \mathrm{R} \& \mathrm{D}$ & 1.021 & 1.136 & 1.133 & 1.097 \\
\hline $\mathrm{F} 2 * \mathrm{R} \& \mathrm{D}$ & 0.861 & 0.867 & 0.737 & 1.165 \\
\hline $\mathrm{F} 3{ }^{*} \mathrm{R} \& \mathrm{D}$ & 1.117 & 0.605 & 0.774 & 0.933 \\
\hline $\mathrm{F} 4{ }^{*} \mathrm{R} \& \mathrm{D}$ & 1.159 & 0.923 & 0.859 & 0.827 \\
\hline nul -2loglikelihood & 669.80 & 683.75 & 683.75 & 646.63 \\
\hline model -2loglikelihood & 607.58 & 604.66 & 612.94 & 610.11 \\
\hline Nagelkerke r2 & $0.158^{\star * *}$ & $0.196^{* * *}$ & $0.177^{\star \star \star}$ & $0.097^{\star *}$ \\
\hline Chi2 adding interaction to full model & 1.31 & 5.30 & 3.29 & 1.50 \\
\hline $\mathrm{n}$ & 502 & 502 & 502 & 502 \\
\hline $\mathrm{n}=1$ & 308 & 212 & 212 & 173 \\
\hline
\end{tabular}

Note: the control variables (see Tables 2 and 3) are not shown.

\section{Conclusions and practical implications}

\section{Interpretations}

Current work on innovation shows that it rests upon internal resources - including, but not limited to, internal R\&D - and upon interactions with heterogeneous economic players and resources outside the firms' boundaries. We contribute to this work by providing new empirical evidence not only of the direct connection between R\&D and use of external information sources on KIBS innovation, but more importantly of the possible complementarity of these two activities. Three broad sets of insights emerge from this study.

First, the results confirm previous studies showing a positive association between openness (i.e. external information sources) and innovation. However, this association is not straightforward. The results reveal that KIBS that value information obtained from clients and suppliers and from generally available sources, including investors, conferences and internet have a higher propensity to innovate. However, we also show that KIBS that value information obtained from universities and from consultants tend to be less innovative. Two elements could explain this result. First, it may indicate that KIBS - unlike manufacturing 
firms - are more closely tied to markets and market-information when it comes to developing innovation. Information obtained from up and down the supply chain and from sources that allow markets to be scanned and monitored (such as conferences and the internet) is more strongly associated with innovation than that of more technical and scientific nature. Second, the results could indicate that KIBS establishments innovate along varied timescales: it is possible that the assimilation of scientific information and know-how is associated with innovation over a timescale that is longer than the three year window that we study, as previous studies using panel data point out (Belderbos et al., 2015; Denicolai et al., 2016). In contrast, the assimilation of market-related information into the innovation process may occur more rapidly.

Second, the results corroborate the idea that $R \& D$ enhances all types of innovation (except for human resource innovation). Although there is some debate about exactly what KIBS respondents consider $\mathrm{R} \& \mathrm{D}$ to be - in particular the extent to which they consider social scientific and market research to be R\&D (Doloreux et al., 2016) - establishments that declare they perform $\mathrm{R} \& \mathrm{D}$ report higher propensities to innovate.

Third, we also provide empirical evidence showing that external sources of information and internal R\&D are independently associated with KIBS' propensity to innovate. Thus, establishments that declare having recourse to both are more likely to have innovated than establishments having recourse to only one or the other. However, the results also reveal that there is no synergy between $\mathrm{R} \& \mathrm{D}$ and external information. Whilst each is associated independently with the propensity of establishments to innovate, there is no indication that combining both would enhance an establishment's propensity to innovate over and above the independent contribution of each. The idea that internal capabilities generated by R\&D could enhance the effectiveness with which external information is assimilated and used in the innovation process is not corroborated by this evidence.

Taken together, these results provide an empirical contribution to an increasingly important literature stream in service innovation that emphasises not only the potential benefits of open innovation, but also the significance of R\&D. It also contributes to wider questions concerning the complementarity, substitutability or independence of internal and external resources in the innovation process. Internal R\&D and external sources of information do not appear to be substitutes in the KIBS innovation process; neither do they seem to be complements in the sense of being synergistic. Rather, they appear to be independent of one another, a third category that has not often been considered in the discussion that surrounds the interplay between internal and external factors of innovation.

It is important to bear in mind that even though the literature suggests a causal relationship between R\&D and innovation and between external information and innovation, our results do not demonstrate this. The nature of our data is such that we can only reveal associations and correlations which, if interpreted causally, can lead to errors because of endogeneity. Indeed, it is plausible that KIBS undertake R\&D after innovating, in order to improve existing products. It is also plausible that information is sought after an innovation is introduced, in order to enhance its marketing, for example. However, even given this limitation, the way in which R\&D and external information combine with respect to innovation is intriguing and runs counter to the idea of synergies occurring within innovative establish- 
ments. If we accept the hypothesis of causal relationships leading from R\&D to innovation and from external information to innovation, then our results reveal that internal capacities $(\mathrm{R} \& \mathrm{D})$ and external capacity (external information) are independently connected to KIBS innovation and that their effects are additive.

\section{Implications for practice and policy}

Further research is required to confirm the causal hypothesis made at the end of the preceding section. If this hypothesis is correct, our results have several implications for practice and policy. Concerning R\&D, they suggest that both policy-makers and managers should place greater emphasis on stimulating internal R\&D if they want to increase the innovation performance of KIBS establishments. In the case of policy-makers the introduction of tax allowances and subsidies could be particularly useful in this respect. Managers, on their side, should consider dedicating more resources to internal R\&D. Such approaches require a clear understanding of what R\&D in the service sector actually consists of: Djellal's et al. (2003) conceptualisation is a good starting point - it goes beyond the scientific and technological definition of R\&D used when manufacturing firms are studied, but requires more empirical exploration and validation.

As for external information sources, the results show their positive influence, especially in the case of market-related sources and ad-hoc sources. Thus, policy initiatives aimed at promoting cooperation between KIBS and innovation partners should be encouraged, such as the development of cooperation platforms and networks aimed at facilitating knowledge and information sharing and mutual learning. Managers should also put into practice mechanisms to foster knowledge and information sharing with other members of the value chain. It should be noted, however, that it is not always necessary to combine $R \& D$ with external information to succeed in innovation. In other words, managers should define their innovation strategies in accordance with the goal pursued (for example, if they want to develop a human resources innovation they should dedicate their resources to fully exploit external information rather than to conduct internal R\&D).

A note of caution is, however, in order: formalised sources of information - knowledge institutions and consultants - are negatively associated with the propensity to innovate over a three year period: whilst we do not suggest that information from these sources depresses the propensity to innovate over the long term, the results do suggest that enhanced innovation should not be expected over the short term if these sources are encouraged. Indeed, our findings on the role of research and academic sources reflect the need for adopting both short-term (market-related) and medium to long term (technical or scientific related) perspectives when designing innovation policies for services (Shearmur, 2015).

This empirical work has limitations. We work with cross-sectional data and not with panel data. This limits the possibility of analysing how the relationship between internal R\&D and external knowledge sourcing evolves over time (Belderbos et al., 2015; Denicolai et al., 2016), and, as noted above, precludes us from addressing endogeneity issues. Thus, causality cannot be established. Another potential limitation is that some associations may be biased because some respondents may tend to provide positive responses to all questions and others 
negative responses (common methods bias, Chang, Van Witteloostuijn, \& Eden, 2010). However, since the results do not suggest straightforward connections between dependent and independent variables, and to the extent that the results reveal no interaction between R\&D and the use of information sources, then this type of bias appears to be limited: common methods bias would tend to enhance positive correlations as well as interaction effects. Finally, the study is based on a Quebec (Canada) sample. Though we see little reason to suspect that the mechanisms investigated are specific to this context, future research should extend our work and focus on other contexts, thereby testing their generalizability.

Bearing in mind these limitations, the results provide some key insights into the KIBS innovation process. In the short-term (three years) it rests more on market-related information than manufacturing innovation does. Unlike for manufacturing, there are no synergistic effects between R\&D and information gathering: rather than being either complements or substitutes, R\&D and external information sources are independent factors of innovation. This type of result furthers our understanding of the similarities, but also of the differences, between KIBS and manufacturing innovation.

\section{Acknowledgements}

The authors acknowledge the financial support from the Social Science and Humanities Research Council in Canada (SSHRC 410-2011-0108). The usual disclaimers apply.

\section{References}

Barge-Gil, A. (2013). Open strategies and innovation performance. Industry \& Innovation, 20(7), 585610. https://doi.org/10.1080/13662716.2013.849455

Battisti, G., Gallego, J., Rubalcaba, L., \& Windrum, P. (2014). Open innovation in services: knowledge sources, intellectual property rights and internationalization. Economics of Innovation and New Technology, 24(3), 223-247. https://doi.org/10.1080/10438599.2014.924745

Becheikh, N., Landry, R., \& Amara, N. (2006). Lessons from innovation empirical studies in the manufacturing sector: a systematic review of the literature from 1993-2003. Technovation, 26(5-6), 644664. https://doi.org/10.1016/j.technovation.2005.06.016

Belderbos, R., Carree, M., Lokshin, B., \& Fernández-Sastre, J. (2015). Inter-temporal patterns of R\&D collaboration and innovative performance. The Journal of Technology Transfer, 40(1), 123-137. https://doi.org/10.1007/s10961-014-9332-4

Bettencourt, L. A., Ostrom, A. L., Brown, S. W., \& Roundtree, R. I. (2002). Client co-production in knowledge-intensive business services. California Management Review, 44(4), 100-128. https://doi.org/10.2307/41166145

Bianchi, M., Croce, A., Dell'Era, C., Di Benedetto, C. A., \& Frattini, F. (2016). Organizing for inbound open innovation: how external consultants and a dedicated R\&D unit influence product innovation performance. Journal of Product Innovation Management, 33(4), 492-510.

https://doi.org/10.1111/jpim.12302

Cassiman, B., \& Valentini, G. (2016). Open innovation: are inbound and outbound knowledge flows really complementary?. Strategic Management Journal, 37(6), 1034-1046.

https://doi.org/10.1002/smj.2375 
Cassiman, B., \& Veugelers, R. (2006). In search of complementarity in innovation strategy: internal $\mathrm{R} \& \mathrm{D}$ and external knowledge acquisition. Management Science, 52(1), 68-82. https://doi.org/10.1287/mnsc.1050.0470

Chang, S.-J., Van Witteloostuijn, A., \& Eden, L. (2010). From the editors: common method variance in international business research. Journal of International Business Studies, 41(2), 178-184. https://doi.org/10.1057/jibs.2009.88

Chen, Y., Wanhaverbeke, W., \& Du, J. (2016). The interaction between internal R\&D and different types of external knowledge sourcing; an empirical study of Chinese innovative firms. $R \& D$ Management, 46(S3), 1006-2013. https://doi.org/10.1111/radm.12162

Clausen, T. H., Korneliussen, T., \& Madsen, E. L. (2013). Modes of innovation, resources and their influence on product innovation: empirical evidence from R\&D active firms in Norway. Technovation, 33(6-7), 225-233. https://doi.org/10.1016/j.technovation.2013.02.002

Cohen, W. M., \& Levinthal, D. A. (1990). Absorptive capacity: a new perspective on learning and innovation. Administrative Science Quarterly, 35, 128-152. https://doi.org/10.2307/2393553

Dahlander, L., \& Gann, D. M. (2010). How open is innovation? Research Policy, 39(6), 699-709. https://doi.org/10.1016/j.respol.2010.01.013

Denicolai, S., Ramirez, M., \& Tidd, J. (2016). Overcoming the false dichotomy between internal R\&D and external knowledge acquisition: absorptive capacity dynamics over time. Technological Forecasting and Social Change, 104, 57-65. https://doi.org/10.1016/j.techfore.2015.11.025

Derudder, B., \& Taylor, P. (2016). Change in the world city network, 2000-2012. The Professional Geographer, 68(4), 624-637. https://doi.org/10.1080/00330124.2016.1157500

Djellal, F., Francoz, D., Gallouj, C., Gallouj, F., \& Jacquin, Y. (2003). Revising the definition of research and development in the light of the specificities of services. Science and Public Policy, 30(6), 415429. https://doi.org/10.3152/147154303781780227

Doloreux, D., \& Shearmur, R. (2013). Innovation strategies: are knowledge-intensive business services just another source of information? Industry \& Innovation, 20(8), 719-738. https://doi.org/10.1080/13662716.2013.856623

Doloreux, D., Shearmur, R., \& Rodriguez, M. (2016). Determinants of R\&D in knowledge-intensive business services firms. Economics of Innovation and New Technology, 25(4), 391-405. https://doi.org/10.1080/10438599.2015.1067001

Freel, M. (2006). Patterns of technological innovation in knowledge - intensive business services. Industry \& Innovation, 13(3), 335-358. https://doi.org/10.1080/13662710600859157

Love, J. H., \& Roper, S. (2009). Organizing the Innovation process: complementarities in innovation networking. Industry \& Innovation, 16(3), 273-290. https://doi.org/10.1080/13662710902923776

Love, J. H., Roper, S., \& Vahter, P. (2014). Dynamic complementarities in innovation strategies. Research Policy, 43(10), 1774-1784. https://doi.org/10.1016/j.respol.2014.05.005

Mansury, M. A., \& Love, J. H. (2008). Innovation, productivity and growth in US business services: a firm-level analysis. Technovation, 28(1-2), 52-62. https://doi.org/10.1016/j.technovation.2007.06.002

Miles, I. (2008). Patterns of innovation in service industries. IBM Systems Journal, 47(1), 115-128. https://doi.org/10.1147/sj.471.0115

Mina, A., Bascavusoglu-Moreau, E., \& Hughes, A. (2014). Open service innovation and the firm's search for external knowledge. Research Policy, 43(5), 853-866. https://doi.org/10.1016/j.respol.2013.07.004

Monteiro, F., Mol, M., \& Birkinshaw, J. (2017). Ready to be open? Explaining the firm level barriers to benefiting from openness to external knowledge. Long Range Planning, 50(2), 282-295. https://doi.org/10.1016/j.lrp.2015.12.008

OECD. (2005). Oslo manual: guidelines for collecting and interpreting innovation data. Oslo Manual (3rd ed.), (162 p.). 
Pina, K., \& Tether, B. S. (2016). Towards understanding variety in knowledge intensive business services by distinguishing their knowledge bases. Research Policy, 45(2), 401-413.

https://doi.org/10.1016/j.respol.2015.10.005

Prajogo, D. I., McDermott, C. M., \& McDermott, M. A. (2013). Innovation orientations and their effects on business performance: contrasting small- and medium-sized service firms. $R \& D$ Management, 43(5), 486-500. https://doi.org/10.1111/radm.12027

Polèse, M., \& Shearmur, R. (2004). Culture, language, and the location of high-order service functions: the case of Montreal and Toronto. Economic geography, 80(4), 329-350.

Rodríguez, A., \& Nieto, M. J. (2012). The internationalization of knowledge-intensive business services: the effect of collaboration and the mediating role of innovation. The Service Industries Journal, 32(7), 1057-1075.

Rodriguez, M., Doloreux, D., \& Shearmur, R. (2016). Innovation strategies, innovator types and openness: a study of KIBS firms in Spain. Service Business, 10(3), 629-649.

https://doi.org/10.1007/s11628-015-0286-X

Rothwell, R. (1991). External networking and innovation in small and medium-sized manufacturing firms in Europe. Technovation, 11(2), 93-112. https://doi.org/10.1016/0166-4972(91)90040-B

Santamaría, L., Nieto, M. J., \& Barge-Gil, A. (2010). The relevance of different open innovation strategies for R\&D performers. Cuadernos de Economia Y Direccion de La Empresa, (45), 93-114. https://doi.org/10.1016/S1138-5758(10)70025-6

Shearmur, R. (2015). Far from the Madding Crowd: slow innovators, information value, and the geography of innovation. Growth and Change, 46(3), 424-442. https://doi.org/10.1111/grow.12097

Shearmur, R., \& Doloreux, D. (2015). Knowledge-Intensive Business Services (KIBS) use and user innovation: high-order services, geographic hierarchies and internet use in Quebec's manufacturing sector. Regional Studies, 49(10), 1654-1671. https://doi.org/10.1080/00343404.2013.870988

Spithoven, A., \& Teirlinck, P. (2015). Internal capabilities, network resources and appropriation mechanisms as determinants of R\&D outsourcing. Research Policy, 44(3), 711-725. https://doi.org/10.1016/j.respol.2014.10.013

Teirlinck, P., \& Spithoven, A. (2013). Formal R\&D management and strategic decision making in small firms in knowledge-intensive business services. $R$ and D Management, 43(1), 37-51. https://doi.org/10.1111/j.1467-9310.2012.00701.x

Tether, B. S. (2005). Do services innovate (differently)? insights from the European innobarometer survey. Industry \& Innovation, 12(2), 153-184. https://doi.org/10.1080/13662710500087891

Tether, B. S., Li, Q. C., \& Mina, A. (2012). Knowledge-bases, places, spatial configurations and the performance of knowledge-intensive professional service firms. Journal of Economic Geography, 12(5), 969-1001. https://doi.org/10.1093/jeg/lbs015

Tödtling, F., Lehner, P., \& Kaufmann, A. (2009). Do different types of innovation rely on specific kinds of knowledge interactions? Technovation, 29(1), 59-71.

https://doi.org/10.1016/j.technovation.2008.05.002

Vega-Jurado, J., Gutiérrez-Gracia, A., \& Fernández-de-Lucio, I. (2009). Does external knowledge sourcing matter for innovation? Evidence from the Spanish manufacturing industry. Industrial and Corporate Change, 18(4), 637-670. https://doi.org/10.1093/icc/dtp023

Vivas, C., \& Barge-Gil, A. (2015). Impact on firms of the use of knowledge external sources: a systematic review of the literature. Journal of Economic Surveys, 29(5), 943-964. https://doi.org/10.1111/joes.12089

Zahra, S. A., \& George, G. (2002). Absorptive capacity: a review, reconceptualization, and extension. Academy of Management Review, 27(2), 185-203. https://doi.org/10.5465/amr.2002.6587995 


\section{APPENDIX}

Table 1A. Population and sample

\begin{tabular}{|l|c|c|}
\hline \multicolumn{1}{|c|}{ KIBS sub-sectors } & Population & Sample \\
\hline Architecture \& engineering services & $21.8 \%$ & $24.5 \%$ \\
Computer services & $27.8 \%$ & $26.1 \%$ \\
Management and technical consultants & $20.9 \%$ & $22.3 \%$ \\
Professional services & $15.2 \%$ & $13.7 \%$ \\
Creative services & $14.5 \%$ & $13.3 \%$ \\
$\mathrm{n}$ & 2508 & 502 \\
\hline Size & \multicolumn{2}{|}{} \\
\hline less than 10 & $43.9 \%$ & $40.2 \%$ \\
10 to 24 & $30.0 \%$ & $30.1 \%$ \\
25 to 50 & $13.7 \%$ & $16.9 \%$ \\
over 50 & $12.4 \%$ & $12.8 \%$ \\
$\mathrm{n}$ (348 obs. missing size in CRIQ data) & 2160 & 502 \\
\hline Geography & $53.1 \%$ & $47.6 \%$ \\
\hline Montreal & $23.3 \%$ & $25.1 \%$ \\
Quebec & $14.3 \%$ & $15.3 \%$ \\
Central towns & $9.3 \%$ & $12.0 \%$ \\
Peripheral towns & 2508 & 502 \\
$\mathrm{n}$ & & \\
\hline
\end{tabular}

Note: the population column corresponds to information from the CRIQ (Centre de Recherche Industrielle du Québec) database from which the sample is drawn.

Table 2A. Principal component analysis: importance of information sources

\begin{tabular}{|l|c|c|c|c|c|}
\hline & F1 & F2 & F3 & F4 & Comm. \\
\hline commercial labs & $\mathbf{0 . 7 5}$ & 0.00 & -0.06 & -0.11 & 0.47 \\
\hline technical college & $\mathbf{0 . 7 2}$ & 0.04 & 0.15 & 0.34 & 0.48 \\
\hline public labs & $\mathbf{0 . 7 2}$ & 0.27 & 0.11 & -0.14 & 0.47 \\
\hline private research institute & $\mathbf{0 . 6 7}$ & 0.10 & -0.12 & -0.14 & 0.58 \\
\hline universities & $\mathbf{0 . 5 4}$ & -0.13 & 0.34 & 0.36 & 0.55 \\
\hline conferences & 0.04 & $\mathbf{0 . 7 8}$ & 0.31 & 0.08 & 0.66 \\
\hline investors & 0.20 & $\mathbf{0 . 6 8}$ & -0.25 & -0.09 & 0.62 \\
\hline internet & -0.02 & 0.31 & $\mathbf{0 . 6 8}$ & 0.00 & 0.49 \\
\hline suppliers & 0.06 & -0.15 & $\mathbf{0 . 6 6}$ & -0.10 & 0.71 \\
\hline consultants & 0.07 & -0.10 & 0.26 & $\mathbf{- 0 . 6 2}$ & 0.55 \\
\hline clients & -0.02 & -0.07 & 0.07 & $\mathbf{0 . 6 7}$ & 0.57 \\
\hline Variance explained (\% total) & 2.38 & 1.31 & 1.29 & 1.16 & $(56 \%)$ \\
\hline
\end{tabular}

Bartlett's test: chi2 $=753.8, \mathrm{p}($ chi2 $=0)<0.0001$.

Note: comm. - communality. F1: scientific and technical sources; F2: investors and conferences; F3: suppliers and internet; F4: clients (+) or consultants (-). 